\title{
The Gender of Pseudotranslation in the Works of Marie-Jeanne Riccoboni, Mme Beccari and Cornélie Wouters
}

\author{
Beatrijs Vanacker
}

\begin{abstract}
While authorship recognition was a challenge for all eighteenth-century aspiring writers regardless of their gender, the social position of women was such that public claims of authorship and ownership over a text were even less self-evident in the public sphere. As will be illustrated in this article, female writers especially made extensive use of transfer strategies (such as translation and pseudotranslation) to establish their authorship, thereby turning paratext and narrative into a dynamic maneuvering space. Considered from a gender perspective, the challenge for eighteenth-century female writers was to gradually "invent" themselves, or rather establish a voice of their own. Taking on a different (cultural) persona - even if only on a paratextual level-could provide them with a discursive "platform" from which they could negotiate their way into the literary field. In order to illustrate this gender-specific emancipatory quality of pseudotranslation, as established mainly in their paratexts, the present article proposes a comparative analysis of their forms and functions in the career and oeuvre of three eighteenth-century French women writers, Marie-Jeanne Riccoboni, Mme Beccari and Cornélie de Wouters, who all made extensive use of pseudo-English fiction.
\end{abstract}

Keywords: pseudotranslation; gender; networks; eighteenth-century novel; paratexts

Résumé : La reconnaissance des droits d'auteurs était tout un défi pour tous les auteurs en herbe du 18 e siècle -hommes et femmes confondus-, mais le statut social des femmes était tel, que toute revendication de droit d'auteur ou de propriété d'un texte était encore moins facile dans l'espace public. Dans cet article, nous montrerons que les auteures plus que les auteurs ont souvent eu recours aux stratégies de transfert (telles que la traduction et la pseudotraduction) afin d'établir leurs droits d'auteur. Le paratexte et le récit devenaient alors un véritable espace de manœuvre dynamique. Dans une perspective du genre, le défi pour les auteures du 18e siècle était de s'inventer progressivement ou plutôt d'établir leur propre voix. Choisir un différent personnage (culturel) -même si cela se passait seulement au niveau du paratexte- leur offrait une « tribune » discursive qui leur permettait de négocier leur entrée dans le monde littéraire. Afin d'illustrer cette qualité émancipatoire sexo-spécifique de la pseudo-traduction, tel que nous le voyons surtout dans les paratextes, nous proposons dans cet article une analyse comparative de leurs formes et fonctions dans la carrière et l'œuvre de trois écrivaines françaises du 18e siècle, Marie-Jeanne Riccoboni, Mme Beccari et Cornélie de Wouters, qui ont toutes généreusement utilisé la fiction pseudo-anglaise.

Mots clés : pseudo-traduction; genre; réseaux; nouvelle du 18e siècle; paratextes

Resumo: Embora o reconhecimento da autoria fosse um desafio para todos os aspirantes a escritores no século XVIII - independentemente de sua identidade de gênero - a posição social das mulheres era tal, que a reinvindicação pública de autoria ou de propriedade em relação a um texto era ainda menos manifesta na esfera pública. Como ilustraremos neste artigo, as escritoras faziam amplo uso de estratégias de transferência (por exemplo, tradução e pseudotradução) a fim de estabelecer sua autoria e, assim, transformar o paratexto e a narrativa em um espaço dinâmico de manobra. Considerado a partir de uma perspectiva de gênero, o desafio das escritoras do século XVIII era o de se "inventarem" aos poucos ou, em outras palavras, estabelecer uma voz própria. Adotar uma persona diferente (cultural) - ainda que apenas ao nível paratextual - fornecia-Ihes uma "plataforma" discursiva a partir da qual podiam negociar sua entrada no campo literário. A fim de ilustrar essa natureza emancipatória específica ao gênero na pseudotradução, sobretudo nos paratextos, o presente artigo propõe uma análise comparativa de suas formas e funções na carreira e obra de três escritoras francesas do século XVIII, Marie-Jeanne Riccoboni, Mme Beccari e Cornélie de Wouters, que fizeram amplo uso da pseudoficção inglesa.

Palavras-chave: pseudotradução; gênero; redes; romance do século XVII; paratextos 
Resumen: Si bien lograr el reconocimiento como autor constituía un desafío para todos los escritores principiantes en el siglo XVIII independientemente de su género, la posición social de la mujer era tal que la declaración abierta de autoría o propiedad sobre un texto por parte de una mujer en la esfera pública era aun menos evidente. Como se ilustra en este artículo, las escritoras en especial hacían amplio uso de estrategias de transferencia (como la traducción y la pseudotraducción) para establecer su autoría, y en este proceso convertían el paratexto y la narrativa en un dinámico espacio de maniobra. Desde la perspectiva de género, el reto para las escritoras del siglo XVIII era "inventarse" gradualmente, o más bien establecer una voz propia. La adopción de una personalidad (cultural) diferente-aunque solo fuera a nivel paratextual—les proporcionaba una "plataforma" discursiva desde la cual podían negociar su entrada en el campo literario. A fin de ilustrar esta cualidad emancipadora específicamente para el género que tiene la pseudotraducción, tal como se muestra fundamentalmente en sus paratextos, el presente artículo propone un análisis comparativo de sus formas y funciones en la carrera y la obra de tres escritoras francesas del siglo XVIII, Marie-Jeanne Riccoboni, Mme Beccari y Cornélie de Wouters, quienes hicieron un amplio uso de la pseudoficción en inglés.

Palabras clave: pseudotraducción; género; redes; novela del siglo XVIII; paratextos

\section{Introduction}

If women have ever proven to be successful in the Sciences and the Arts, now is the time. [...] Every day we encounter women in the Arts who deserve the laurel wreath. It is the author of the "Brochure" that is commented upon in this article who has presented us with a phenomenon of a very different genre, a foreign writer who writes works of invention in our own language. (Journal de Littérature 129-130) ${ }^{1}$

This quote, taken from the Journal de littérature, des sciences et des arts, provides a comment on Le nouveau Continent, conte, par une dame angloise (1783), written by Cornélie Wouters. Yet, in his laudatory account, the reviewer attributes this allegorical tale based on the American Revolution to a "foreign writer", cunningly (or unwittingly?) accepting the information added to the full title: "par une dame anglaise". Le nouveau continent is in fact an example of what is nowadays defined as a "pseudotranslation", namely, a text presented as a translation, but for which no actual source text (pre)exists. Written at a time when this type of pseudo-English fiction had become a literary trope (Martens \& Vanacker 351), the reference to its paratextual construction becomes all the more relevant when it is considered in relation to the main argument of this quote: the recognition of (fictional) literature penned by a woman.

As for the author of Le nouveau Continent, researchers have identified her as Brussels-born, French-speaking Cornélie Wouters, ${ }^{2}$ who published both pseudoEnglish fiction and actual translations from the English. What is more, Wouters was one of many female writers for whom (implicit) authorship-negotiated and established through translation, imitation, and/or even pseudotranslation-was a common

\footnotetext{
1 Original version $(\mathrm{OV})$ : « Si jamais les Femmes ont prouvé qu'elles pouvaient se montrer avec succès dans la carrière des Sciences \& des Arts, c'est surtout à présent. [...] Nous voyons également tous les jours des femmes qui méritent le laurier des arts. II était réservé à l'auteur de la Brochure dont il est question dans cet article, de montrer un phénomène d'un genre nouveau, une Étrangère qui écrit dans notre langue des Ouvrages d'imagination. " All translations from the French are the author's, unless indicated otherwise.

${ }^{2}$ For a biographical note on the author, see: siefar.org/dictionnaire/en/Corn\%C3\%A9lie_Wouters.
} 
practice, and even a necessary strategy to gain critical acclaim in the Republic of Letters.

Indeed, while recognition of authorship was a tedious process for all aspiring writers at the turn of the eighteenth century-regardless of their gender-the social position of women was such that the prevailing doxa made public claims of authorship even less plausible. As will be illustrated in this article, female writers especially, because of their social and cultural position, made extensive use of transfer strategies (such as translation and pseudotranslation) before obtaining a more established form of authorship (see Lanser). In his seminal article "Pseudotranslations and their significance" (1985), Gideon Toury already points to the general emancipatory effect of pseudotranslations, without specific reference to gender. ${ }^{3}$ According to Toury, pseudotranslations offer "a convenient and relatively safe way of breaking with sanctioned patterns and introducing novelties into a culture" (48), but can also serve as (para)textual strategies of authorial (de/re)construction. As it appears throughout history, this textual practice was indeed often used by authors who "[sought] to change course and who would rather have [their] new endeavour dissociated from what [they] ha[d] come to stand for" (49). Considered from a gender perspective, however, the challenge for eighteenth-century female writers was not so much to re-invent themselves as authors, as to gradually "invent", or rather establish voices of their own, as has been discussed by Julia Candler Hayes and Hillary Brown for the English and German contexts respectively. ${ }^{4}$ Taking on a different (cultural) persona-even if only on a paratextual level-provided female writers with a discursive "platform" from which they could negotiate their way into the literary field. Given this shared experience, the gender-specific emancipatory quality of pseudotranslation is thus best explained when examined from a macrostructural stance, from the viewpoint of these writers' careers and oeuvre, instead of focusing on particular texts. This article thus provides a comparative analysis of pseudotranslations written by three eighteenth-century French women writers, Marie-Jeanne Riccoboni, Mme Beccari and Cornélie de Wouters, who all made extensive use of pseudo-English fiction.

\section{Gendered (pseudo)translations}

It would seem that one of the keys to answering the question of the functional link between pseudotranslation and female authorship lies in the literary critique quoted in this article's epigraph. Although it remains unclear whether the reviewer was deceived by the paratextual construction of Englishness when referring to the supposed origins of the work's author, or simply decided to play along, that is not the point here. Nor could it be considered the primary goal for these women writers. Indeed, they all published their pseudotranslations in the later stages of the pseudotranslation fashion that took hold of the French literary system in the eighteenth century (Vanacker 2016)

\footnotetext{
${ }^{3}$ In his article "Pseudogynies hétéronymiques" (pp. 177-186), Jean-François Jeandillou examines the many forms and functions of pseudo-female authorship (pseudogynies), including but not primarily focusing on cases of pseudotranslation (e.g. Mérimée or Pierre Louÿs).

${ }^{4}$ In her chapter "Gender, Signature, Authority", Julia Candler Hayes convincingly uses the concept of "middle voice" to describe early modern women writers' use of translation, as "a way to articulate something 'between' active and passive", in the sense of an intermediate form of literary agency (161). In her theoretical article on pseudotranslation, Şehnaz Tahir Gürçağlar cites gender as one of the "additional motives [...] behind pseudotranslations", which "researchers have started revealing [...] over the years" ("Pseudotranslation" 520).
} 
and which—by sheer repetition-had already made the translation claim less credible in the eyes of the general reading public. Why, then, did these women resort to pseudotranslation? In this respect, it is noteworthy that the abovementioned literary review contains acclamatory comments on Wouters' style that refer to certain cultural stereotypes generally linked with English writing (such as simplicity and artlessness ${ }^{5}$ ). According to the reviewer, these set "la dame angloise" apart from other "writers of her sex":

In justice to the author, her style is not complex [tourmenté] or affected [maniéré], as is the style of some of her sex who believe that the language of books should be exactly the opposite of that of conversation. $[\ldots] .^{6}(133)$

Interestingly, this account of Le nouveau Continent thus establishes a connection between stylistic originality and the writer's supposed foreignness an association through which difference and otherness also seem to designate a qualitative distinction.

Inspired by the French public's persistent Anglomania (see Grieder), Wouters was one of several female writers who combined strategic window-dressing and a genuine interest in English culture and literature throughout their oeuvre. ${ }^{7}$ When looking into the approximately 40 pseudotranslations from English that were published from the 1730s to the 1770s, one cannot fail to notice that a large number were written by anonymous or, if identified, lesser-known writers (a notable exception being Antoine François Prévost). Interestingly, only a few of the identified writers appear more than once in this list and these are mainly female. In the second half of the eighteenth century especially, French women writers such as Marie-Jeanne Riccoboni, but also lesser-known writers such as the enigmatic Mme Beccari, Cornélie Wouters, Mme Bournon-Mallarme or Constance de Cazenove d'Arlens turned to pseudo-English fiction. Many indeed published their work under a disguised name, while numerous texts appeared anonymously, with authorship being established only years later. This was also the case for the three authors of the selected corpus, of whom Marie-Jeanne Riccoboni (1713-1792) is arguably the most critically acclaimed. ${ }^{8}$ A prolific novelist, translator and dramatist, Riccoboni not only translated (freely) from the English (see infra), but also wrote many of her novels "in the English taste": her Lettres de Mistriss Fanni Butlerd (1757) were soon followed by Lettres de Juliette Catesby à Milady

\footnotetext{
${ }^{5}$ See, for example, Langford, Englishness Identified.

${ }^{6} \mathrm{OV}$ : « Je dois cette justice à l'Auteur, que son style n'est pas tourmenté \& maniéré comme celui de quelques personnes de son sexe qui s'imaginent que la langue des Livres doit être précisément le contraire de celle de la conversation. »

${ }^{7}$ As Carrie Klaus notes, "[t]he Wouters consider intersections of French and English literatures and cultures in all their published works, including both original texts and translations. Cornélie Wouters, in particular, seems unendingly fascinated by-indeed, obsessed with-differences in the character of the two peoples" ("Une école des moeurs" 2).

${ }^{8}$ As argued by Jan Herman and Paul Pelckmans in their introduction to the edited volume Mme Riccoboni, romancière, épistolière, traductrice (2007), secondary literature on Riccoboni was relatively scarce before the 1990s, when the "recovery project" for women writers gained momentum. Recent research on Riccoboni includes Susan S. Lanser, Fictions of Authority; Heidi Bostic, The Fiction of Enlightenment: Women of Reason in the French Eighteenth Century; Marijn S. Kaplan (ed.), Translations and Continuations: Riccoboni and Brooke, Graffigny and Roberts.
} 
Henriette Campley (1759) and Histoire de Miss Jenny ${ }^{9}$ (1764). Finally, in her last novel Riccoboni returned to pseudo-English fiction when she published Lettres de Milord Rivers à Sir Charles Cardigan (1776). As for the other two novelists, the current scholarly attention is fairly limited, but they were both widely read at the time. ${ }^{10}$ Cornélie Wouters's first pseudo-English novel appeared in 1782, Les Aveux d'une femme galante, ou Lettres de madame la marquise de ${ }^{* * *}$ à myladi Fanny Stapelton, soon followed by Le nouveau continent (1783). At the end of a prolific career during which she also produced translations of English plays and novels ${ }^{11}$ (some of which were co-translated with her sister, Marie Wouters), she published La belle Indienne (1798), supposedly translated from English and for which the author's name, Cornélie de Vasse, appeared in full on the title page (the previously used title of baroness being cautiously suppressed in revolutionary France). Mme Beccari's oeuvre consisted-as far as we know-entirely of pseudo-English fiction: Lettres de Milady Bedford, traduites de l'anglois (1769), Mémoires de Lucie d'Olbéry, traduits de l'anglois, by Madame de $B^{* * *} \mathrm{G}^{* * *}(1770)$, Milord d'Amby, Histoire angloise (1778) and Mémoires de Fanny Spingler ou Les Dangers de la calomnie, Histoire Angloise (1781).

As for the reasons underpinning these women's use of pseudotranslation, it is clear that the recurrent appearance of (pseudo)translations from English, and their female authorship, cannot be ascribed exclusively to financial gain or commercial strategies. In order to fully understand the literary-historical and sociological implications of female pseudotranslatorship, however, a first and necessary step would be to examine the (pseudo)translators' archives, defined by María Constanza Guzmán as a "repository of translator's texts and statements" (179). Following Guzmán's definition, these archives include both metatexts on and by the translator and his/her work and paratextual material more directly linked with the translations, such as footnotes or prefaces. Moreover, as Guzmán emphasizes, the translator's archive is a "dynamic and organic composition" (179) and-to a certain extentimplies a relational conceptualization of translation, not only because it enables us "to refer to this collection of texts and documents in relation to a translating subject", but also because "in turn, these documents enter in relation among themselves and with larger narratives and other forms of discourse" (180). In line with Guzmán's definition, the present article aims to expose some of the traces of (pseudo)translatorship throughout the entire oeuvre of these women writers, as it places pseudotranslations in relation to actual translations by the same authors, private documents (such as correspondence) and translations of the respective pseudotranslations. At the same time, the focus on pseudotranslation, as mimicry of-and in relation to-translation, will add a new layer to the relational dynamics of the translators' archives, ${ }^{12}$ as it allows a more radical questioning of institutionalized hierarchies and binaries by exploring the

\footnotetext{
9 The full title would be: Histoire de miss Jenny, écrite et envoyée par elle à milady, comtesse de Roscomonde, ambassadrice d'Angleterre à la cour de Danemark.

${ }^{10}$ Both authors are mentioned in the Dictionnaire des femmes des Lumières (2015) by Valérie André and Huguette Krieff; Beccari is briefly referenced in Emily A. Crosby, Une romancière oubliée, Mme Riccoboni : sa vie, ses œuvres, sa place dans la littérature anglaise et française du XVIlle siècle (1970) and in Eva Martin Sartori, The Feminist Encyclopedia of French Literature (1999); as for Cornélie Wouters, Carrie Klaus' work made an important contribution to bringing this author to scholarly attention. 11 Both novels she translated were written by female authors: Juvenile Indiscretions (1786), by Agnes/Anna Maria Bennett and The Platonic Marriage (1787) by Mrs. Cartwright.

12 In the same context, one could refer to Sherry Simon's definition of translation "as an intensely relational act: one which establishes connections between text and culture, between author and reader" (83).
} 
creative permeability between original work and translations as well as between (presumed) authorship and (pretended) translatorship.

In what follows, my analysis will raise two interrelated questions. The first part will bring to the fore the manifold ways in which these (pseudo)translators' profiles took shape and evolved throughout the different paratexts, not just in the original French works, but also in some of their (actual) translations. My approach here is also to be associated with Anthony Pym's notion of "network transfer maps", as developed in Method in Translation Studies (1998). Although, as Gürçağlar rightly notes, Pym does not provide a clear definition of "network" (Gürçağlar 728), his "incremental" and "experimental" approach (Pym, Method 91) suits the qualitative and dynamic angle on which this comparative analysis is based, firstly, because in addition to the main focus on pseudotranslations and the research question of gendered authority, I also intend to follow the networks' threads as they unfold across languages and cultures, and allow for the authors' individual patterns and idiosyncratic strategies to shine through. ${ }^{13}$ Moreover, Pym's initial choice to establish wider "transfer" maps, rather than "a conception of translation history as a story about translations and nothing but translations" widens the "range of inquiry to include nontranslational [and pseudotranslational] modes of transfer" (Method 92). Indeed, even if pseudotranslations lack an actual source text, they nevertheless imply modes of cultural transfer, established in the paratext but also echoed on the story level, be it through cultural stereotypes, or distinctive stylistic elements. Although mapping the entire "network of translated narratives" (Guzmán 182) exceeds the scope of this article, a comparative reading of the paratexts will bring out both the great diversity and significant parallels in the forms and functionalities of the pseudotranslation paradigm with regard to eighteenth-century female authorship.

In addition to exploring these networks, this article will also briefly address the emancipatory effect of the pseudo-English framework mentioned by Toury on a microlevel, paying specific attention to the novels' formal and thematic features and how they uphold the fiction of translation from within the narrative. Indeed, if choosing this particular paratextual setting potentially contributed to advancing the writers' careers on an institutional level, one should also consider its metatextual implications. The question as to whether and how it could provide a fictional manoeuvring space to experiment with form, style and narrative voice, as suggested by the reviewer of Wouters' Le nouveau Continent, could indeed be connected to that of (institutionalized) authorship.

\section{Paratexts - negotiating (female) authority through (pseudo)translation}

Upon considering the (pseudo)translators' trajectory, some similarities indeed appear, both in terms of quantity (recurrence) and of form, as subtle changes in authorial/translatorial staging occur in all three cases that designate an (often intertextual) process of gradual authorial recognition. Even in the oeuvre of Cornélie Wouters-whose stories appeared at a time when the pseudotranslation paradigm was already past its prime-it is striking that she also resorted to a paratextual mise

\footnotetext{
${ }^{13}$ See Pym: "People cannot be reduced to sets of sociological categories. They cannot simply be slotted into languages or cultures; they create and act in their own space; they open and configure their own distances" (“Cross-Cultural Networking" 746).
} 
en scène of Englishness at the start of her career, albeit to a lesser extent then Riccoboni or Beccari (see infra).

Cornélie Wouters's first novel Les aveux d'une femme galante, ou lettres de Madame la marquise de ${ }^{* * *}$ à Lady Stapleton (1782) capitalizes on the work's supposed "Englishness" in the second part of the title. Additionally, the supposed "authenticity" of the novel is again emphasized in a translator's note added to Fanny Stapleton's first letter. As it is added to the novel's fifth letter-well into the narrativethis note seems to have been designed to bring the narrative effects of the English make-believe to the readers' mind, inviting them to "play along". The presumed editor-or Wouters herself-also connects "Englishness" with style, as did the reviewer of Le nouveau continent, which seems to suggest a general assumption that formal features such as style were indeed defined-and even determined-by the writer's cultural identity. While the modern reader may find it difficult to take these editorial notes at face-value, they nevertheless indicate that eighteenth-century pseudo-English fiction was more than just window-dressing. At the very least, they illustrate a certain awareness of its narrative implications and the make-believe it entailed:

The editor of these letters felt obliged not to change anything about the style of those written by Lady Fanny Stapleton. The reader will easily recognize that they were written by an Englishwoman. (8) ${ }^{14}$

As for the question of authorship, as might be expected in line with the authenticity claim, the title page does not provide any information on the work's actual author, nor is Wouters listed as translator or editor. The dedication, however, makes mention of the fact that the text is, indeed, an original (French) work and, moreover, the debut ("ce premier essal") of an anonymous author. Her second work, L'art de corriger et de rendre les hommes constants (1783), does feature Wouters' name ("par Mme la Baronne de Vasse") in its second edition (1789), and also includes an interesting epigraph, addressed "To the ladies" ("Aux dames"). In this short paratext, the author comes to the fore as a female writer, emphatically entrusting the work to the "protection of my sex" ("if you welcome it with kindness, who would doubt its success?"15). This additional preface in the second edition is in clear contrast with the work's initial preface (1783), written in the more hesitant style of a debut author ("the author, whose literary career has only just begun, hardly dares to hope to obtain the public's approval"16). Interestingly, Wouters elaborates on the gender aspect when she constructs, again, an anonymous writerly posture (Meizoz) in the paratext of Le nouveau Continent (1783), an allegorical tale about the American War of Independence published in the same year as the first edition of $L$ 'art de corriger. The story is indeed attributed to "an English lady" ("une dame angloise"), which serves to promote the text's cultural "otherness" to the French public. Under the same disguise, however, Wouters also retrospectively claims authorship of her previous work, Les aveux d'une femme galante, through the addition of the line "auteur des Aveux d'une

\footnotetext{
14 OV: «L'éditeur de ces lettres s'est cru obligé de ne rien changer au style de celles écrites par Lady Fanny Stapleton. Le lecteur reconnaîtra facilement qu'elles sont d'une Anglaise. »

${ }^{15} \mathrm{OV}$ : "la protection de mon sexe. [...] si vous l'accueillez avec bonté, qui pourra douter de son succès?"

$16 \mathrm{OV}$ : «L'auteur, dont la carrière littéraire commence à peine, n'ose guère se flatter d'obtenir l'approbation du public. »
} 
dame galante". Her actual name only appears on the title page in later works, most of which are actual (and not pseudo)translations of English texts.

Similarly, Riccoboni chose to publish her first novels as supposed translations from English (even when an actual English setting is lacking, as is the case in Le marquis de Cressy). ${ }^{17}$ The strategic reasons behind this conscious construction of fictional Englishness are presumably manifold. On a purely paratextual level, the translator's posture may have indeed contributed to establishing her position as a woman writer within the field of prose fiction, as can also be derived from the gradual reconfiguration of this paratextual Englishness in later editions of these first novels. In Lettres de Juliette Catesby's first edition (1757), the paratextual make-believe is indeed on full display, not only through the supposition of translation ("traduites de l'anglais") but also through the mention of a fictitious author (Adelaïde de Varançai). In later editions, Riccoboni is first referred to as auteur-e trois étoiles, before being acknowledged on the title page, as is the case in a 1790 bilingual (French-English) edition of the work. Whereas both Fanni Butlerd (1759) and Histoire de Mr. le marquis de Cressy are presented as translations in their first editions (1758), despite the latter's very French-sounding title, this paratextual marker also disappears in later editions. As for Histoire de Miss Jenny (1764) and Lettres de Milord Rivers (1777), they are both stories set (at least partly) in England or featuring English protagonists, yet neither is identified as a translation on the title page. Clearly, by that stage, the author's established position and authority as a writer rendered any recourse to such elaborate paratextual strategies unnecessary.

While this trajectory towards authorial self-display can only be deduced from a careful comparison of the title pages in Riccoboni's and Wouters' respective oeuvres, it is far more apparent in the case of Lettres de milady Bedfort, traduites de l'anglois (1769) ${ }^{18}$ and les Mémoires de Lucie d'Olbery, traduites de l'anglais (1770). Both works are now attributed to a female writer whose nom de plume was Mme Beccari, but whose real identity remains a mystery. However, in Beccari's case we are presented with extensive prefatory comments in all four pseudo-English novels, which, when considered together, pave an interesting path towards authorial recognition. In the first two, supposedly translated novels, Beccari explicitly minimizes her role as a "translator". In the second novel, Lucie d'Olbery, the so-called anonymous translator is identified (again retrospectively) as the "author" of the previous work, Milady Bedfort. At the same time, in the novel's preface, the intrinsic ethical and aesthetical values of the story are emphatically brought to the fore, thus indirectly paving the way for Beccari's (future) recognition as an author of respectable prose fiction, in line with Riccoboni's oeuvre. Additionally, a close reading of the first two prefaces shows a subtle shift in terminology between Milady Bedfort and Lucie d'Olbery, which also affects Beccari's initial posture as an (anonymous) translator: through the use of words such as "écrire" ("writing") and "livre" ("work"), which subtly suggest the idea of creative, original work instead of referring to her novels as authentic "mémoires", Beccari gradually marks her own authorial voice, even from within the general

\footnotetext{
17 James $C$. Nicholls overtly simplifies her positioning in his introduction to her Letters: "Mme Riccoboni was one of the first victims of that eighteenth-century malady known as anglomania" (25).

${ }^{18}$ Apart from Lettres de milady Bedfort, traduites de l'anglois (1769) and Mémoires de Lucie d'Olbery, traduites de l'anglais par Madame de B... G...., auteur des Lettres de milady Bedford (1770) two histoires anglaises have been attributed to the same author: Milord d'Ambi, histoire anglaise, par Madame Beccary, Auteur des Lettres de Lucie d'Olbery (1778) and Mémoires de Fanni Spingler, histoire anglaise (1781).
} 
"translation" framework. When, from the third novel onwards, her authorial claim is further emphasized in the respective prefatory texts, this evolution is also mirrored by a change in the title: instead of a translation, Beccari's last two novels are presented as histoire anglaise, thereby explicitly acknowledging their English character as purely fictional, rather than ascribing them to a supposed act of translation. In the preface to Fanny Spingler, histoire angloise (1781), we thus find a confident, emancipated author who repeatedly refers to her own authorial stance, for instance when she addresses her introductory remarks to "Mes lecteurs" ("my readers") and warmly refers to "mon heroïne" ("my heroine").

Additionally, it should be noted that in Riccoboni's and Wouters' oeuvres, pseudotranslation also functions in connection with other forms of inter/transcultural fiction writing. Both authors were also real translators, and even reportedly translated the same work, David Garrick's play The Clandestine Marriage,$^{19}$ at different points in their careers. In the eighteenth century, "translation" did not necessarily imply a faithful rendering of the source text, even when the latter existed, and both translators seem to have eagerly adapted the play to the tastes and cultural framework of their French readers. As is well known, Riccoboni also published a very free adaptation of Henry Fielding's Amelia, ${ }^{20}$ although the 1762 edition mentions that the novel was "traduit de l'anglois", ${ }^{21}$ as was the case of her first successful novels Fanni Butlerd and Juliette Catesby. Yet in this case, Riccoboni does provide an authorial paratext in which she comes forward with much more confidence and audacity. Moreover, her preface to Amélie, which takes the form of a letter addressed to the editor, Humblot, forms an intriguing illustration of the contiguity between translation, imitation and pseudotranslation. When Riccoboni describes the rather unorthodox editing process of Amélie with a mixture of disarming nonchalance and witty self-assertion, the reference to her "thèmes anglais" and the "gros amas de papier écrit" seems to designate a (disorderly) writing process rather than the careful rendering of a source text:

I managed to produce a large pile of written paper, where I got so easily lost that I found it impossible to find the common thread. Someone more patient than I am took on the task of search for it, numbered all the little pieces of paper scattered on my desk, and in the chaos of my English themes, found the sequence of this special work. She suggested I send it to you, so here it is. $(3)^{22}$

\footnotetext{
${ }^{19}$ See Annie Cointre's comparative analysis in the anthology Translators, Writers, Mediators: "Garrick and Colman's The Clandestine Marriage translated by Mme Riccoboni and the Baronne de Vasse". In the introduction, she first addresses the uncertainties regarding the attribution of both translations, but still grounds her double analysis on the assumption of both Riccoboni's and Wouters' (Baronne de Vasse's) translatorship. For a more detailed account of Wouters' theatre translations, see Carrie Klaus. ${ }^{20}$ Amélie, roman de Mr Fielding, traduit de l'anglois par Mme Riccoboni, Paris, chez Brocas et Humblot, 1762.

${ }^{21}$ Likewise, Wouters imitates The Platonic Marriage (1786) in French, with no mention of the original authoress on the title page.

${ }^{22} \mathrm{OV}$ : « Je parvins enfin à faire un gros amas de papier écrit, où je me perdis si bien, qu'il me fut impossible d'en retrouver le fil. Une personne plus patiente que moi, s'est occupée à le chercher; a numéroté toutes les petites feuilles éparses dans mon secrétaire; \& parmi le fatras de mes themes anglois, a recouvré la suite de ce singulier ouvrage. Elle m'a conseillé de vous l'envoyer; \& le voilà. »
} 
Moreover, Riccoboni further elaborates on the topic of literary arbitrariness in the next paragraph, when she cunningly displays her pragmatic, not to say strategic view of novelistic étiquettage, by making her responsibility as a translator dependent on the work's reception: "If the book disappoints, too bad for the English author, we can claim that it is a literal translation. If it is read; we will boast of the infinite art with which we added, reduced, corrected, and embellished the original" 23 (3).

As the subtle title changes in both Riccoboni's and Beccari's oeuvres seem to indicate, the recurrent use of paratextual markers of Englishness (which evolve from pseudotranslation to pseudo-English fiction in both cases) can be seen as a sign of the gradual negotiation process through which these women writers, each at their own pace, sought to find a voice in the literary marketplace. Wouters makes use of a similar scénographie, while insisting on stylistic differences so as to impose upon the reader a certain way of reading these letters; that is, as if they were actually written à l'anglaise.

\section{Translations-mediating pseudotranslations}

The question then arises as to whether this pseudo-English setting, to some extent transcultural in nature through its French form and English character(s), might have been beneficial to establishing these authors' positions in the literary marketplace of their time. In the case of Mme Riccoboni, finding a definite answer to that question is not an easy task: as we know, her work was largely read in different countries, sometimes both in the original version and in translation, and highly valued by French, English, German and Dutch readers alike. ${ }^{24}$ Yet, it appears that the critical reception of Riccoboni's novels has focused mostly on the stylistic and thematic features of the author's sentimental fiction, rather than judging the probability of their supposedly English character. On the other hand, some of the German translators do seem to carry forward-and even elaborate on-the deceit of translation. To give but one example, Riccoboni's first novel, Fanni Butlerd, is still attributed to Adelaïde Valançai in the 1800 translation Liebe und Untreue. In the 1761 translation of Juliette Catesby, the title page capitalizes on the make-believe of an English original: Briefe der Milady Juliane Catesby, an die Milady Henriette Campley, ihre Freundin, aus dem englischen und französischen ins teutsche übersetzt. ${ }^{25}$ The existence of an English original is further suggested in the translator's preface, where the German version is explicitly dedicated to readers who are unfamiliar with both French and English. ${ }^{26}$ At the same

\footnotetext{
${ }^{23} \mathrm{OV}$ : « Si le Livre déplaît, tant pis pour l'auteur anglois; nous dirons que cela est traduit à la lettre. Si on le lit; nous nous vanterons de l'art infini avec lequel nous avons ajouté, retranché, corrigé, embelli notre original. »

${ }^{24}$ For close readings of Italian and English translations of Riccoboni's Fanni Butlerd and Juliette Catesby, see Annie Cointre, Florence Lautel-Ribstein, and Annie Rivara, La traduction du discours amoureux (1660-1830) (2006). For the reception of Riccoboni's novels in Germany, see Nathalie Ferrand, "Les romans de Mme Riccoboni en Allemagne au XVIIle siècle", (2008).

${ }^{25}$ The same strategy applies to the Dutch translation of Miss Jenny, which mimics the make-believe of the English original, even to the point of omitting the (actual) French original version: Historie van Miss Jenny, of het misleide weeskind, Door haar zelfs in 't Engelsch geschreven. In 't Nederduitsch vertaald [History of Miss Jenny, or the Misguided Orphan, Written by the Author in English, Translated into Dutch].

26 "I believe I'm doing no minor favour to those experts and amateurs of witty writings, who do not master the English or French languages." OV: "So glaubte ich den Kennern und Liebhabern der witzigen Schriften, welch der englischen und französischen Sprache nicht kundig [sind], keinen geringen Dienst zu beweisen."
} 
time, some German translators make clever use of the imaginary original developed by authors like Riccoboni to insert additional found manuscripts of their own invention, supposedly translated from the English. For example, a few years after the publication of the French novel, a continuation-or rather, an "answer"-to Briefe der Milady Juliane Catesby (1761) was published in German with the title Die Antwort des Sir Manly an die Milady Grafin von Sunderland. In denen Briefen der Milady Catesby die als eine Fortsetzung derselben dienen kan[n]. Thus, Juliane Catesby is a telling example of the hybrid process of cultural transfer generated in many eighteenth century literary translations-oscillating between translation and original creation. What is more, the German "translation" of Riccoboni's last pseudo-English novel, Lettres de Milord Rivers, gave rise to an entirely new story, again created under the guise of translation: Briefe von und an Milord Rivers-aus dessen Originalpapiere übersetzt (1782) mimics the English framework of Riccoboni's pseudotranslation (as the same English protagonists appear), but transports these to Germany, instead of France, thus generating a completely new intercultural "narrative". This continuation of the English setting thus at least suggests that it was not always Riccoboni's literary authority, but also her use of a pseudo-English narrative that appealed to the (German) translators' creative imagination.

The hypothesis that the "English framework" might have added some value to the international reception of these women writers' pseudotranslations gains further support in the case of a lesser known novelist like Mme Beccari. Indeed, the fact of this pseudo-English setting makes it less surprising that some of her works were translated into German and Dutch, regardless of their second-rate status and the critical reception in France. In this respect, the preface of a Dutch translation of Beccari's last novel by the female writer Betje Wolff, Les dangers de la calomnie, ou Mémoires de Fanny Spingler (1781) is a case in point. Although the connection was never explicitly stated by the French novelist, the relationship between the novels' protagonists, the virtuous Fanny and her perfidious lover Lord D'orblac, was instantly perceived by French critics to be a deliberate imitation of Richardson's famous couple Clarissa and Lovelace. In L'année littéraire, D'orblac is explicitly presented-and judged-as a distortion of Richardson's most famous libertine, since he "embodies all Lovelace's vices, without sharing his grace, or sparkling mind" (66). ${ }^{27}$

Wolff translated Beccari's novel some years after she published her famous Dutch epistolary novel, De Historie van mejuffrouw Sara Burgerhart (1782), together with Aagje Deken. As a writer and a translator, she has long been considered a key figure in the rise of the novel genre in the Low Countries in the eighteenth century, which raises the question Piet Buijnsters asks in his Betje Wolff biography (223): why would Wolff translate a novel by Mme Beccari, clearly considered a second-rate novelist by contemporary critics? Suzan Van Dijk certainly makes a point when she notes that Wolff had a specific interest in translating women writers (246), in that she, like other female writers, was intent on creating an international network of literary women, for which translation was one of the more visible strategies. Other than that, Wolff's extensive foreword, where she translates the larger part of the French preface by Beccari and explicitly mentions her as the original author ("from which I borrowed the subject" $\left.[\mathrm{v}-\mathrm{vi}]^{28}\right)$, is particularly informative about the translator's intentions. Not only is

27 OV: « qui a tous les vices de Lovelace, sans avoir rien de ses grâces, sans avoir une étincelle de son esprit. »

${ }^{28}$ Cf. OV: "Mevrouw Beccari, aan wie ik mijn onderwerp ontleend heb." 
she very insistent on the novel's moral value, depicting the exemplary character of its heroine, but, more importantly, Wolff uses Beccari's model to develop a theoretical treatise on the novel. As she herself indicates: "in my country, any instructions on how to write a novel are still lacking" (vi). ${ }^{29}$ It seems, then, that for Wolff this translation fits in with a more general writing programme which is indebted, again, to Richardson's Clarissa. References to the depiction of Richardson's characters are abundant and, whereas the French reviewer criticized the lack of grace and genius in the character of D'orblac - in comparison with Lovelace-Wolff underscores the love of virtue that both Richardson's and Beccari's unhappy heroines seem to share. It should not come as a surprise, then, that in order to substantiate her theory about the novel, Wolff, who clearly has ambitions to establish the features of the Dutch novel ("een vaderlandschen roman"/"a domestic novel"), chose to translate a novel "in the English dress", the setting of which was sufficiently similar to Richardson's internationally acclaimed model.

\section{Fictions-experimenting with (pseudo-English) style and voice}

The first two parts of this article engaged with the various ways in which Riccoboni's, Wouters' and even Beccari's status as an author became institutionalized through (pseudo)translation, as they gradually formed a transcultural network of the texts and agents involved. But the emancipatory potential of the pseudotranslation paradigm also reverberates on a fictional level, through the stylistic and thematic premises that are shaped in and by the presupposition of translation. Indeed, if choosing this particular paratextual setting potentially contributed to advancing these writers' careers on an institutional level, one should also consider its poetic implications. The question as to whether and how it could provide a fictional manoeuvring space to experiment with form, style and narrative voice, as suggested by the reviewer of Wouters' Le nouveau Continent, could indeed be connected to that of (institutionalized) authorship. For instance, while a lot of in-depth research has been done on the emancipatory potential of pseudotranslation in Riccoboni's early novels, in which she deploys epistolary fiction in order to "subvert the socio-political structures" (Cook 126) ${ }^{30}$ and conventions that restrict her heroines' fictional lives, her last novel, Lettres de Milord Rivers (1776), received far less critical attention. Yet, in more than one way, this last novel stands out in Riccoboni's oeuvre. Compared to her earlier work, Milord Rivers reads more like a philosophical novel, as the central love story between Rivers and his pupil is clearly subordinate to the development of more reflective letters on a great variety of sociocultural themes. Also, in Milord Rivers, this philosophical emphasis appears to be more embedded in the novel's English character than in earlier novels, such as Juliette Catesby and Le marquis de Cressy, ${ }^{31}$ where the supposed Englishness hardly surpasses the level of cultural windowdressing. This leads us to the following question: if, for various-and not in the least

\footnotetext{
${ }^{29}$ OV: "te meer dewijl wij, zo veel mij bekend is, in onze Vaderlandsche spraak nog geen Voorschrift hebben om een Roman te maken."

${ }^{30}$ Cook adds: "Of course, Fanny is English, a national identity chosen not at all gratuitously by Riccoboni"; because "for many of the philosophes the adjective anglais connoted a range of liberal values" (124-125).

${ }^{31}$ This is pointed out by Heidi Bostic, who also notes: "As A. Sol observed Riccoboni's novels tend to eschew a simple either/or, instead exploring the fundamental ambiguities with which eighteenth-century women had to live" (129).
} 
commercial-reasons, Riccoboni wrote her first novels à la mode anglaise, why did she veer away from this setting in some of her later novels (such as Lettres d'Elisabeth Sophie de Vallière, 1772), only to return to this strategy in her last novel?

As we can read in one of her letters to Robert Liston, Riccoboni herself liked to emphasize the work's unique set-up, for instance when stating that she was in fact not working on a novel (whereas she used the term frequently when referring to her other works), but on a bundle of letters ("I'm still writing the letters of that Englishman ${ }^{32} 344$ ). Later on, when the work was already published, she even referred to it as "une brochure" (398). While she never shied away from criticizing some forms of sentimental fiction in her private correspondence, she describes Milord Rivers as a bundle of letters that contain "a gentle critique of the current shift in our mores"33 (399), in reference to the novel's sociocultural criticism which makes it stand out against her more sentimental novels. The (at first surprisingly) dominant perspective of Milord Rivers, as the typical English philosopher and a counterpart to Riccoboni's previous (mostly female) protagonists, thus suddenly becomes much more significant and functional. A priori, Rivers seems simply to stand for a different type of mode de vie, which can be prototypically associated with the reasonable and pragmatic English approach to life. Yet, through this same character, Riccoboni explores the rhetorical potential of a pseudo-English voice and character more fully than in her previous novels, playing with contemporary ideas on cultural identity both in her depiction of Milord Rivers as a fictional character and his engagement with the cultural debates of that time. Admittedly, as Heidi Bostic notes, in this novel female characters also play an important part, in that they reflect Riccoboni's own views on the role of women in society. Nevertheless, a great deal of the author's attention focuses on the individual de/reconstruction of cultural stereotypes through Rivers' voice, and how these processes are informed by a close connection between argumentation and feeling. Milord Rivers is depicted as a critical yet modest observer of mankind, constantly sceptical about his own capacity to define national character ("My God, my friend, I do not possess your doctor's skills. I distinguish so much variety in the capital's citizens that today's impressions make me doubt the ones I made yesterday, and rather than defining my thoughts, I get new ones constantly" [L.XXX] ${ }^{34}$ ). These moments of psychological self-analysis are artfully played out as markers of social criticism, for instance when he criticizes judgmental fellow travellers. However, since he also plays the sentimental lead in Mme Riccoboni's fictional design, it is interesting to see how he in turn becomes entrapped in a stereotypical dichotomic reasoning on cultural identity when it comes to judging women's mores and manners. Indeed, being in love with an Englishwoman, he recurrently defends the idea that French women ("obligeantes et polies"/"obliging and polite") are more harmless in their use of coquetterie than their English rivals ("dédaigneuses et railleuses"/"disdainful and mocking", 48).

It has already been suggested in previous studies that Riccoboni's choice of English characters was not merely a sign of the times, but also added an argumentative layer to the fiction. By depicting English heroines, Riccoboni could play with the connotations of Englishness, such as "a certain range of liberal values thought

\footnotetext{
${ }^{32} \mathrm{OV}$ : « je poursuis les lettres de cet Anglais »

${ }^{33} \mathrm{OV}$ : « une critique douce sur le changement actuel de nos mœurs. »

34 OV: «Ma foi, mon ami, je n'ai pas l'habilité de ton docteur. Je crois apercevoir tant de variété dans les habitans de la capitale, que les remarques du jour élèvent mes doutes sur celles de la veille, et loin de pouvoir fixer mes idées, j'en reçois à chaque instant de nouvelle. »
} 
to be lacking in French society; the simpler life of a society not dominated by courtly aristocracy; the sentiments of the heart; liberty of thought and speech" (Cook 124). If this was the case for the early work, I would like to argue that it applies even more to Milord Rivers, which was written near the end of Riccoboni's highly successful career as a writer, translator and cultural "mediator" tout court. Instead of merely serving as a legitimation strategy, at that time long overdue, it seems to have acted as a fictional framework through which Riccoboni could engage more critically, and subtly, with the (social and argumentative) functionalities of cultural prejudice, thereby putting to use the narrative form of epistolary fiction. This specific take on novel writing is also suggested by Riccoboni herself in her private correspondence. Indeed, Riccoboni's letters at times also function as a discursive platform where the author discusses her personal views on her work and how it was intended. It is in one of these letters that Riccoboni attributes-although tongue-in-cheek-a programmatic value to Milord Rivers' letters:

I'm still writing the letters of that Englishman which seemed so mean to you. I have given him an amiable character and I am confident to show your nation that I am incapable of low revenge. She [the English nation] treats us with contempt, I treat her well. ${ }^{35}$ (344)

If, in Riccoboni's case, personal documents are a valuable source of information on the motivation underpinning some of her choices as an author and (pseudo)translator, neither Beccari nor Wouters left similar authentic sources. Yet, Wouters' fiction is interspersed with metafictional comments that also provide a solid basis for analysis. Similar to Riccoboni's Milord Rivers, in Wouters' Les aveux d'une femme galante, which was published only a few years later, the pseudo-English nature of parts of the letters is implemented on a diegetic level. In this novel, Wouters approaches the theme of love and seduction from a decidedly female point of view, yet adds a cultural perspective through the confrontation between French légèreté and galanterie, in la Marquise's letters, and English constancy, in Fanny Stapleton's account of her true love for Count Saint-Albin. At first, the use of cultural dichotomy ${ }^{36}$ seems rather predictable. Interestingly, however, this dichotomy is also "framed" on a discursive level. The novel's epistolary mode indeed engenders a dual narrative perspective which not only reflects the story's cultural premises but also allows for metatextual comments on epistolary style and story-telling from both narrators. When la Marquise at first refuses to confide her true feelings, cultural differences thus become closely intertwined with the narrative act: "The confessions you're expecting, my dear friend, are rarely expressed to a woman, and especially to an Englishwoman, whose principles regarding gallantry are very different from ours" (2). ${ }^{37}$ This creative entwinement of narrative and cultural identity is even more visible in Fanny Stapleton's letters (and the love story they convey), supposedly written in English, but which the

$35 \mathrm{OV}$ : « Je poursuis les lettres de cet Anglois qui vous parurent si méchantes. Je lui ai donné un caractère aimable et suis bien aise de montrer à votre nation que je suis incapable d'une basse vengeance. Elle nous traite indignement, moi je la traite bien."

${ }^{36}$ OV: « Vous me direz peut-être: mais les Angloises sont plus constantes que les Angloises, et par conséquent moins galantes. Cela se peut, ma chère amie: mais vos Anglois ne sont pas si séduisants que nos François. »

37 OV: «Les aveux que vous exigez, ma chère amie, se font rarement à une femme, \& surtout à une Angloise, dont les principes en galanterie diffèrent beaucoup des nôtres. » 
reader only gets to read in French "translation". Apart from the editor's note already mentioned, Fanny herself frequently comments on her letter writing, for instance when she initially apologizes for the lack of "style" and "interest" in her letters, again ascribed to cultural identity: "Marchioness, my adventures are of so little interest, that I am convinced already that you will be bored by them: the humidity of our weather and the black coal smoke bring about a certain melancholy that makes us tend to languor" (16). ${ }^{38}$ However, Fanny then explains how she feels drawn to participate in the epistolary exchange ("I am determined to pay back your confidence with mine" ${ }^{39}$ ), the fascination of which-for both letter writers and, one could assume, intended readers-appears to lie precisely in the stylistic and cultural differences it engenders. And it is not just Fanny who points out the cultural characteristics underpinning her letter writing, when she states that their "less lively colours"/"couleurs moins vives" (27) reflect the nation's melancholy and languor; la Marquise, in her turn, also notices and values its distinguished English flavour as an important asset of Fanny's epistolary voice: "Please continue your story; I like the beginning; it is very English" (37). ${ }^{40}$

However, the Marquise does not further define the English flavour she finds so appealing in Fanny's letters, which leaves the reader guessing at their specific nature. Its distinctive character could be associated with the sentimental theme of the novelsince the first letters are an illustration of female constancy, or with couleur localethrough frequent references to English taste and habits, such as afternoon tea or love of the country-or even with style-since Fanny repeatedly admits having a rudimentary and natural pen ("I do not know how to structure my story" [8-9] ${ }^{41}$ ). Although these utterances on style are not as such mirrored by any noticeable difference in style, by adding these comments Wouters seeks to appeal to the French (anglophile) readers' imagination and stimulate their interest in the story. The game of make-believe is thus not simply confined to the paratext, but extended to a reflection on matters of style and language. As was the case for Riccoboni's Milord Rivers, this metatextual layer materializes by virtue of the novel's epistolary form, which further heightens the focus on voice and (cultural) character.

\section{Conclusion}

Following these (pseudo)translator's traces as documented in paratexts, epitexts and even permeating the narrative itself, one can learn a great deal about the possible ramifications of pseudo-English texts in eighteenth-century France (and beyond). On a theoretical level, these case studies thus add further support for the recent scholarly focus, in the fields of both translation studies and comparative literature, on "the theoretical potentials and complexities of the phenomenon [of pseudotranslation]" (Gürçağlar 520).

From the specific viewpoint of gender and authorship, they clearly attest to the intrinsic emancipatory value of pseudotranslation-as fictional make-believe and as a paratextual framework-for women writers. First, the gradual negotiation and revaluation process that emerges in all three authors' oeuvres-each of them lowering

\footnotetext{
${ }^{38} \mathrm{OV}$ : «Marquise, mes aventures sont si peu intéressantes, que je suis sûre d'avance qu'elles vous ennuieront : un climat humide, \& la fumée noire du charbon de terre, engendrent en nous une mélancolie qui nous porte à la langueur. »

39 OV: « Je suis décidée à vous rendre confidence pour confidence »

40 OV: «Continuez-moi [votre récit]; le début me plait; il est tout à fait anglais. »

41 OV: « Je ne sais comment je pourrai mettre de l'ordre dans mon récit. »
} 
the "translator's mask" at their own pace and by means of specific paratextual markers-is a striking illustration of the general uneasiness still felt by women writers in regard to the recognition of their authorship and intellectual authority in the second half of the eighteenth century. At the same time, each of these individual cases serves to illustrate that, in a literary context defined by the creative contiguity between translation and original - a contiguity both reified and critically addressed through the practice of pseudotranslation-authorship was often obtained and established "transnationally". As can be deduced from the selected corpus, such "transnational authorship" could take on many forms and functions, often emerging from a complex and idiosyncratic network of texts and agents.

Only through a combined analysis of paratexts, metatexts and reception processes, then, can we assess the role of "gender" in eighteenth-century pseudotranslations more adequately, not just as an obstacle for female writers in the initial publication process, but-perhaps surprisingly-also as a distinctive characteristic to which specific value was added by critical readers (Wouters) and translators (Beccari-Wolff). As was illustrated in the final part of this article, the supposed English identity-such as Wouters' dame angloise-constructed in the paratext enabled these writers to create a (sometimes polyphonic) fictional narrative through which they were at liberty to critically engage with sociocultural conventions and stereotypes and to experiment with the articulation of style, cultural identity and narrative form.

\section{References}

André, Valérie, and Huguette Krieff. Dictionnaire des femmes des Lumières. Droz, 2015.

Anon., Année Littéraire, "Mémoires de Fanni Spingler, Histoire angloise », Tome II, Lettre III, 1781.

Anon., Journal de Littérature, des Sciences et des Arts, t. 2, Paris, 1783.

Beccari. Lettres de Milady Bedfort, traduites de l'anglois. Paris, 1769.

---.Mémoires de Lucie d'Olbery, traduits de l'anglois. Paris, 1770.

---. Milord d'Ambi, histoire angloise. Paris, 1778.

---. Mémoires de Fanny Spingler, histoire angloise. Paris, 1781.

---. De Gevaaren van den Laster, in een Briefwisseling tussen Miss Fanni Spingler, en haare vrienden: door E. Bekker, wed. Wolff. 's Graavenhaage, 1791.

Bostic, Heidi. The Fiction of Enlightenment. Women of Reason in the French Eighteenth Century. University of Delaware Press, 2010.

Buijnsters, Piet. "Betje Wolff als vertaalster: opvattingen en praktijk." Ars \& Ingenium. Studien zum Übersetzen. Festgabe Frans Stoks zum 60. Geburtstag, Maarssen, 1983, pp. 219-230.

Candler Hayes, Julie. Translation, Subjectivity and Culture in France and England, 1600-1800. Stanford UP, 2009.

Cauquelin, Anne. L'art du lieu commun. Du bon usage de la doxa. Seuils, 1999.

Cointre, Annie. Florence Lautel-Ribstein, and Annie Rivara, editors. La traduction du discours amoureux (1660-1830). CETT, 2006.

Cointre, Annie. "Garrick and Colman's The Clandestine Marriage. translated by Mme Riccoboni and the Baronne de Vasse." Translators, Interpreters, Mediators: 
Women Writers 1700-1900, edited by Gillian Dow, Peter Lang, 2007, pp. 7382.

Cook, Elisabeth. Epistolary Bodies: Gender and Genre in the Eighteenth-Century Republic of Letters. Stanford UP, 1996.

Crosby, Emily A. Une romancière oubliée, Mme Riccoboni : sa vie, ses œuvres, sa place dans la littérature anglaise et française du XVIIle siècle. Slatkine Reprints, 1970.

Ferrand, Nathalie. "Les romans de Mme Riccoboni en Allemagne au XVIIle siècle." Mme Riccoboni. Romancière, épistolière, traductrice, edited by Jan Herman, Kris Peeters and Paul Pelckmans, Peeters, 2008, pp. 287-301.

Grieder, Josephine. Anglomania in France: 1740 - 1789, Fact, Fiction and Political Discourse. Droz, 1985.

Gürçağlar, Şehnaz T. "Pseudotranslation on the Margin of Fact and Fiction." $A$ Companion to Translation Studies, edited by Sandra Bermann and Catherine Porter, Wiley-Blackwell, 2014, pp. 516-527.

---. "Chaos before Order. Network Maps and Research Design in DTS," Meta, 524, 2007, pp. 724-743

Guzmán, María Constanza. "Translation North and South: Composing the Translator's Archive." Traduction et conscience sociale/Translation and Social Conscience: Around the Work of Daniel Simeoni, special issue of TTR : traduction, terminology, rédaction. vol. 26, no. 2, 2013 (published in 2016), pp. 171-191.

Jeandillou, Jean-François. "Pseudogynies hétéronymiques." Poétique, vol. 2, no. 162, 2010, pp. 177-186.

Kaplan, Marijn S., editor. Translations and Continuations: Riccoboni and Brooke, Graffigny and Roberts. Pickering \& Chatto, 2011.

Klaus, Carrie. "Une école des moeurs \& de la morale: How the Wouters Sisters made English Theatre French." De la traduction comme commentaire au commentaire de traduction. Palimpsestes, vol. 20, 2007, doi:10.4000/palimpsestes.95. Accessed 28 June 2015.

Langford, Paul. Englishness Identified: Manners and Character, 1650-1850. Oxford UP, 2000.

Lanser, Susan S. Fictions of Authority: Women Writers and Narrative Voice. Cornell UP, 1992.

Martens, David and Beatrijs Vanacker, editors. Scénographies de la pseudotraduction, special issue of Les lettres romanes, vol. 67, no. 3-4.

Nicholls, James C., editor. Madame Riccoboni's Letters to David Hume, David Garrick and Sir Robert Liston 1764-1783. SVEC, 1976.

Pym, Anthony. Method in Translation History. St Jerome Publishing, 1998.

---. "Cross-Cultural Networking: Translators in the French-German Network of Petites Revues at the End of the Nineteenth Century," Meta, vol. 52, no. 4, pp. 744762.

Riccoboni, Marie-Jeanne. Amélie, sujet tiré de M. Fielding, CEuvres complètes de Mme Riccoboni, nouvelle édition, Avec une Notice sur la vie et les ouvrages de l'auteur, et ornée de six gravures. 1762. Foucault, 1818.

---. Lettres de Mistriss Fanni Butlerd, à Milord Charles Alfred de Caitombridge, Comte de Plisinte, Duc de Raslingth, Écrites en 1735; Traduites de l'Anglois en 1756, par Adélaïde de Varançai. Amsterdam, 1757.

---. Lettres de Juliette Catesby à Milady Henriette Campley, son amie. Amsterdam, 1759. 
---. Briefe der Milady Juliane Catesby, an die Milady Henriette Campley, ihre Freundin, aus dem englischen und französischen ins teutsche übersetzt. Frankfurt, 1761.

---. Briefe der Milady Juliane Catesby an die Milady Henriette Campley ihre freundin, durch eine neue Vortsetzung vermehrte Ausgabe. Frankfurt und Leipzig, 1761.

---. Histoire de miss Jenny, écrite et envoyée par elle à milady, comtesse de Roscomonde, ambassadrice d'Angleterre à la cour de Dannemark. Brocas et Humblot. 1764.

---. Lettres de Milord Rivers à Sir Charles Cardigan entremêlées d'une partie de ses correspondances à Londres pendant son séjour en France, Humblot, 1776. 2 vols. Edited by Olga B. Cragg, Droz, 1992.

---. Briefe der Mistriss Fanni Butlerd an Lord Karl Alfred von Kaitombridge, aus dem französischen neu verteutscht. Frankfurt am Main, 1781.

---. Briefe von und an Lord Rivers, während seines zweiten Aufenthalts in Deutschland. Aus dessen Originalpapieren übersetzt. Leipzig, 1782.

Sartori, Eva Martin. The Feminist Encyclopedia of French Literature. Greenwood, 1999.

Simon, Sherry. Gender in Translation: Cultural Identity and the Politics of Transmission. Routledge, 1996.

Toury, Gideon. Descriptive Translation Studies and Beyond. John Benjamins, 1995.

Vanacker, Beatrijs. Altérité et identité dans les "histoires anglaises" au XVIII siècle. Contexte(s), reception et discours. Brill/Rodopi, 2016.

Van Dijk, Suzan, "Vrouwen en hun Republiek der Letteren. Internationale contacten tussen schrijfsters voor de feministische golven." Tijdschrift voor Vrouwenstudies, no. 17, 1996, pp. 235-253.

Wouters, Cornélie. Les Aveux d'une femme galante, ou Lettres de madame la marquise de ${ }^{* * *}$, à myladi Fanny Stapelton. Paris, 1782.

---. Le Nouveau continent. Paris, 1783.

---. L'Art de corriger et de rendre les hommes constans. Paris, 1783. 